undertaken in the hope that it may facilitate the passage next session of legislation on similar lines. The promoters have a two-fold objective; first, to bring some relief to farmers who are suffering from the depredations of rabbits coming from neighbouring property, and secondly, by reducing the stock of wild rabbits in the country, to reduce the amount of suffering inflicted annually by the rabbit-trapping industry. A leaflet written by a Bedfordshire farmer, with illustrations by a Bedfordshire farm labourer, has been issued in support of the Bill, and copies of this, together with a memorandum summarizing the details of the Bill, may be obtained from ULAWS (The University of London Animal Welfare Society), 42 Torrington Square, London, W.C.1.

\section{Prehistory and Quaternary Geology of the Sahara}

THE first international meeting for the Study of the Prehistory and Quaternary Geology of the Sahara was held under the auspices of the Musée de l'Homme, Paris, on June 27-30. Sir Robert Mond, who has arranged for the publication of the results, was président d'honneur, and Prof. P. Rivet, who kindly allowed the magnificent organization of his new Museum to be used, was president. Archæological papers predominated at the meeting, and of these the larger number dealt with the numerous and important rock-drawings and rock-paintings of the Desert. This being the first general meeting of men of science working in different areas of almost half a continent, it was more exploratory than definitive, the primary purpose being to familiarize workers with progress in other parts. Perhaps, not least important was the opportunity for personal contact. A second meeting will be held four years hence. However, certain more concrete results were obtained. Machinery was set up for forming a bibliography of rock paintings and drawings. It was agreed that in the pre cameline era two clear periods of rock pictures were to be found throughout the entire area, an early 'level' of hunters and a later one of cattle breeders. Further subdivisions appear at present to be local, and it also seems as if the hunters differed in different localities, whereas the cattle breeders were probably the same people throughout the Sahara. Furthermore, there was common accord that one genre of pottery is found throughout, though it varies slightly locally. The biggest uniform group stretches across the entire southern half and is the same as the Early $C$-Group culture of Nubia and a similar culture found by the Robert Mond Expedition at Armant. Its date of entry into Egypt is fixed at about 2500 B.c. The papers read at the meeting will be published later in full.

\section{Iron Age Site in Wiltshire}

THE experiment of the Prehistoric Society in undertaking excavation on an archæological site in Wiltshire, hitherto known only from air survey, with the view of providing at the same time a training ground for young archæologists (see NATURE, July 9, p. 65) has fully justified itself so far as concerns the archæological results, which, after a month's ex- cavation, have proved of considerable interest. The site selected was the lesser of two enclosures at Woodbury on the hill south of Salisbury. A test excavation had shown that it had been thickly inhabited at a period definitely belonging to the Early Iron Age. According to a preliminary report (The Times, July 20) not only did excavation confirm the existence of the pits inferred from the evidence of the air survey, but it also revealed others not so indicated. Further study of conditions affecting the two groups will no doubt prove of value in the future development of the technique of air photography. In addition to isolated pits and post-holes, there is a large group of intercommunicating shallow pits appearing on the photographs as what has come to be known as "the Great Dark Mark". Finds included a blue bead of the Early Iron Age and quantities of Early Iron Age pottery. No Romano-British remains were found. The pits were evidently for storage; and the excavators conclude that such pits, with their vertical sides, cannot be regarded, as hitherto, as pit-dwellings. The burnt material adduced as evidence of hearths, it has been shown at Woodbury by intensive study in situ, was not formed in the pits, but was thrown into them. The discovery of a similar enclosure on a hill above Harnham about a quarter of a mile away leads to the suggestion that the site now occupied by Salisbury was surrounded by a ring of such enclosures. There are others at Cockey Down and north-east of the aerodrome at Old Sarum. The complicated nature of the site will probably necessitate a second season's excavation, although the duration of the present term of digging will depend upon the funds available, towards which contributions are needed. These may be addressed to the Hon. Treasurer, Department of British and Medieval Antiquities, British Museum, Bloomsbury, London, W.C.1.

\section{Destructive Earthquake in Greece}

ON July 20, about 2.15 a.m. Athens was shaken by an earthquake which lasted about 10 seconds, and probably had its epicentre in the Island of Eubœa (Negroponte) in the AEgean Sea. The depth of focus appears to have been normal (10-15 km.), and the area in which the earthquake was destructive was about 5,000 square miles. Eight villages near Oropos were seriously damaged, seventeen people were killed, and about eighty injured. There appears to have been some fault displacement near Halcoussie. No damage appears to have been done in the capital. Greece is well known to be a centre of seismic activity in historic times, though of recent years the epicentres have been chiefly about $38.5 \mathrm{~N}$. lat., $22.5 \mathrm{E}$. long., which is north-west of Athens. Very close to the present epicentre was an earthquake which occurred on April 27, 1894, and which did damage over an area of 3,000 square miles. Permanent surface movement in this 1894 shock was for thirty-five miles along a well-known fault parallel to the Gulf of Eubcea. The ground to the north-east side of the fault was moved slightly to the north-west and depressed by varying amounts from place to place, but never greater than $5 \mathrm{ft}$. 